\title{
Effects of Litter on Seedling Emergence and Seed Persistence of Three Common Species on the Loess Plateau in Northwestern China
}

\author{
Rui Zhang ${ }^{1}$, Xiaowen Hu' ${ }^{1 *}$, Jerry M. Baskin ${ }^{2}$, Carol C. Baskin ${ }^{2,3}$ and Yanrong Wang ${ }^{1 *}$ \\ ' State Key Laboratory of Grassland Agro-Ecosystems, College of Pastoral Agriculture Science and Technology, Lanzhou \\ University, Lanzhou, China, ${ }^{2}$ Department of Biology, University of Kentucky, Lexington, KY, USA, ${ }^{3}$ Department of Plant and \\ Soil Sciences, University of Kentucky, Lexington, KY, USA
}

OPEN ACCESS

Edited by:

Maria Tsiafouli,

Aristotle University of Thessaloniki,

Greece

Reviewed by:

Yong Liu,

Hunan Plant Protection Institute,

China

Nikos Krigas,

Aristotle University of Thessaloniki,

Greece

*Correspondence:

Xiaowen $\mathrm{Hu}$

huxw@lzu.edu.cn

Yanrong Wang

yrwang@/zu.edu.cn

Specialty section:

This article was submitted to Agroecology and Land Use Systems,

a section of the journal

Frontiers in Plant Science

Received: 24 July 2016 Accepted: 18 January 2017 Published: 31 January 2017

Citation:

Zhang R, Hu X, Baskin JM, Baskin CC and Wang Y (2017)

Effects of Litter on Seedling Emergence and Seed Persistence of Three Common Species on the Loess Plateau in Northwestern China. Front. Plant Sci. 8:103. doi: 10.3389/fpls.2017.00103
Litter accumulation resulting from land use change (enclosure) is one of the key variables influencing seedling recruitment and consequently the regeneration of plant populations and seed persistence in the soil seed bank. A better understanding of the effects of litter on seed germination and seedling emergence is crucial for developing a new set of indicators for grassland ecosystem health and for grassland management policy. We investigated the effects of seed position in litter and amount of litter covering the seed on seedling emergence and seed persistence of three common species on the Loess Plateau in northwestern China. Seed position beneath the litter layer provided a suitable environment for seedling emergence of the three species. A moderate amount of litter $\left(160 \mathrm{~g} / \mathrm{m}^{2}\right)$ was beneficial for seedling emergence of the small-seeded species Stipa bungeana and Lespedeza davurica from seeds from beneath the litter layer. The largeseeded species Setaria glauca was more tolerant of a high amount of litter $\left(240 \mathrm{~g} / \mathrm{m}^{2}\right)$ than the two small-seeded species. Seed persistence in the soil differed among the three species and also was affected by seed position in litter and amount of litter cover. The proportion of viable seeds of Stipa bungeana and Setaria glauca on top of the litter layer increased with an increase in amount of litter. Seedling emergence and seed persistence varied significantly among species, amount of litter and seed position in litter. A moderate amount of litter and seeds positioned beneath the litter layer were better for seedling recruitment than for those on top of the litter layer. A high amount of litter was more favorable for persistence of seeds positioned on top of the litter than for those beneath the litter. Our study showed that maintaining litter amount between 80 and $160 \mathrm{~g} / \mathrm{m}^{2}$ is optimal for $S$. bungeana dominated grassland on the Loess Plateau. We suggest that litter amount can serve as a guide for monitoring and managing grassland ecosystems, as it is an indicator of ecosystem processes that are essential for biodiversity conservation and restoration.

Keywords: grassland ecosystem health, Lespedeza davurica, litter, Loess Plateau, seedling emergence, seed persistence, Setaria glauca, Stipa bungeana 


\section{INTRODUCTION}

Litter plays an important role in influencing community structure (Grime, 2001) and may affect the establishment of new individuals as a form of post-death, plant-plant interaction (Facelli and Pickett, 1991a). A litter layer acts as a mechanical barrier to seedling emergence, changes physical factors of the environment, such as soil temperature and moisture and light quantity and quality and indirectly modifies the chemical environment by releasing allelochemicals that affect seedling establishment and seedling growth (Facelli and Pickett, 1991a; Holmgren et al., 1997; Ruprecht et al., 2010a). Thus, litter may influence the diversity and dynamics of plant communities, and consequently productivity and health of ecosystem (Fowler, 1986; Gibson and Good, 1987; Facelli and Pickett, 1991b; Quested et al., 2005; Ruprecht et al., 2010b; Eckstein et al., 2011).

The effect of litter on seedling emergence and consequently seedling recruitment varies with environmental conditions, litter amount, seed position and seed traits (Hovstad and Ohlson, 2008; Wellstein, 2012; Egawa and Tsuyuzaki, 2013; Loydi et al., 2013). A meta-analysis showed that litter had an overall negative effect on seed germination and seedling establishment in grassland, old field and forest ecosystems (Xiong and Nilsson, 1999), but recent studies indicated that this might not be the case in grassland ecosystems (Quested and Eriksson, 2006; Donath and Eckstein, 2008; Loydi et al., 2013). For dry grasslands or grasslands under water-limited conditions, low to medium amounts of litter had a positive effect on seedling emergence and recruitment. However, a high amount of litter will inhibit seed germination and seedling establishment by reducing light quality and quantity beneath the litter layer, by preventing seeds on top of the litter from reaching the soil or by preventing roots of seedlings that germinate on top of the litter layer from reaching the soil surface (Xiong and Nilsson, 1999; Eckstein and Donath, 2005; Donath and Eckstein, 2010; Loydi et al., 2013).

In addition to amount of litter, the responses of plants to litter depend on seed position in/on the litter layer. Seeds can be positioned on top, within or beneath the litter layer depending on whether litter input occurs before, during or after seed rain (Wellstein, 2012). For example, seedling emergence of Pimpinella saxifraga, Leontodon autumnalis, and Sanguisorba officinalis was significantly higher for seeds beneath the litter layer than for those on top of it or on the bare soil (Wellstein, 2012). In contrast, germination of forest understory Carex species was lower for seeds beneath the leaf litter than for those on top of the litter layer (Vellend et al., 2000).

The soil seed bank is an important consideration in community ecology, and above-ground vegetation dynamics, and knowledge of seed persistence in the soil plays an important role in the conservation of rare species, in maintenance of plant communities and in restoration of vegetation following disturbances (Van der Valk and Verhoeven, 1988; Hodgson and Grime, 1990; Jones and Esler, 2004; Bossuyt and Honnay, 2008; Michaela and Wolfgang, 2009; Baskin and Baskin, 2014; Long et al., 2015). Seed persistence is affected by many factors, such as seed characteristics, species characteristics and abiotic and biotic conditions in the pre-dispersal and post-dispersal environments (Long et al., 2015). Kettenring et al. (2006) reported that seed bank development is not only determined by the standing vegetation but also by modification of microenvironments through litter accumulation. Litter derived from the standing vegetation can act as a seed trap and thus prevent seed germination. Non-germinated seeds in the soil are the prime determinant of the composition of the seed bank, and development of a thick layer of litter may promote seed bank development (Egawa et al., 2009).

The Loess Plateau in China is characterized by an arid to semiarid climate. Heavy rain storms easily erode the loess soil, and low vegetation cover and degradation of grasslands by overgrazing have long been a serious problem that has hugely impacted grassland animal husbandry and ecological security in this area (Unkovich and Nan, 2008; Zhao et al., 2013). To prevent further soil erosion and desertification and to protect and restore the grassland, the Chinese government implemented the Returning Farmland to Grassland and Returning Rangeland to Grassland programs in 2000 and 2003, respectively (Lin et al., 2013). However, the effects of restoration programs on grasslands are controversial. Some studies showed that ecological restoration programs had a positive effect on vegetation (Pettit et al., 1995; Liu et al., 2008), and others indicated that reasonable grazing or mowing was conducive to maintenance of the natural vegetation (Dumont et al., 2009; Cheng et al., 2014). Further, long-term enclosure had a negative effect on plant regeneration in semiarid areas on the Loess Plateau due to the accumulation of litter that inhibited seed germination and thus indirectly affected natural regeneration (Cheng et al., 2006). Thus, litter accumulation during ecological restoration may play a key role in the productivity and health of the grassland ecosystem on the Loess Plateau. Understanding the role of litter in regulating seed germination, seedling recruitment and the soil seed bank will aide in developing a new set of indicators for grassland ecosystem health.

Yet, there is little information (Rotundo and Aguiar, 2005; Liu et al., 2016) on how amount of litter and seed position in the litter jointly influence seedling emergence and seed persistence; specifically, no such study has been conducted on the Loess Plateau. Stipa bungeana, a dominant perennial grass on the Loess Plateau, plays an important role in protecting the soil from erosion and reducing water loss by runoff ( $\mathrm{Hu}$ et al., 2014). Setaria glauca, a summer annual grass, is native to Eurasia (Steel et al., 1983), but it has become a cosmopolitan grass weed throughout the temperate region (Culpepper and Sheldon, 1999) and is common in the study area. Lespedeza davurica, a $\mathrm{C}_{3}$ perennial leguminous shrub, is a dominant species in the natural grassland community on the Loess Plateau of China (Xu et al., 2013). Also the dominant species $S$. bungeana produces a relatively high amount of litter during the growing season. Thus, we select these three common species and the litter of $S$. bungeana as object to answer the following questions. (1) What amount of litter is beneficial for seedling emergence and seed persistence of the dominant species Stipa bungeana and its accompanying species Setaria glauca and Lespedeza davurica? (2) How do seed position and its 
interaction with amount of litter affect seedling emergence and seed persistence?

\section{MATERIALS AND METHODS}

\section{Study Site and Species}

Field experiments were conducted from 28 July 2013 to 28 December 2014 on Yuzhong Campus (N35 $57^{\prime}, \mathrm{E} 104^{\circ} 09^{\prime}$, $1720 \mathrm{~m}$ above sea level) of Lanzhou University, Gansu Province, China. Precipitation and temperature data collected on the Yuzhong Campus showed that mean annual precipitation is $350 \mathrm{~mm}, 60 \%$ of which occurs from July to September, and mean annual temperature is $6.7^{\circ} \mathrm{C}$.

\section{Seed Collection}

Seeds of S. bungeana and S. glauca were collected at the Yuzhong experimental station in July 2013 and those of L. davurica at the same site in October 2012. Seeds of each of the three species were collected from more than 50 individuals and kept in paper bags at room temperature $(20-45 \% \mathrm{RH} ; 18$ $25^{\circ} \mathrm{C}$ ) until used in experiments. Other than the after-ripening that may have occurred during storage, no dormancy-breaking treatments were given to the seeds before they were used in the experiments. The 1000-seed mass determined using eight replicates of 100 seed samples was $1.14 \pm 0.04 \mathrm{~g}, 3.56 \pm 0.05 \mathrm{~g}$ and $1.86 \pm 0.04 \mathrm{~g}$ for S. bungeana, S. glauca, and L. davurica, respectively.

\section{Seedling Emergence: Effect of Seed Position in Litter, Species and Amount of Litter}

The effects of seed position in litter, species and amount of litter on seedling emergence were studied in the field on the Yuzhong Campus from 28 July to 6 October 2013, during the rainy season. Cheng et al. (2006) indicated that the amount of litter was $40-90,80-140,120-280$, and $160-240 \mathrm{~g} / \mathrm{m}^{2}$ in Stipa bungeana-dominated grassland enclosed for $0-5,6-10,11-15$, and $16-20$ years, respectively, and that it peaked $267 \mathrm{~g} / \mathrm{m}^{2}$ for this grassland enclosed for 11-15 years. Thus, we used 0,80 , 160 , and $240 \mathrm{~g} / \mathrm{m}^{2}$ to mimic the natural conditions. There were seven treatments: control (no litter, seeds placed on bare soil), seeds on top of $80 \mathrm{~g} / \mathrm{m}^{2}$ litter layer, seeds beneath the $80 \mathrm{~g} / \mathrm{m}^{2}$ litter layer, seeds on top of $160 \mathrm{~g} / \mathrm{m}^{2}$ litter layer, seeds beneath $160 \mathrm{~g} / \mathrm{m}^{2}$ litter layer, seeds on top of $240 \mathrm{~g} / \mathrm{m}^{2}$ litter layer and seeds beneath $240 \mathrm{~g} / \mathrm{m}^{2}$ litter layer. Thus, there were three seed positions (on top of the litter layer, beneath litter layer, on bare soil $=$ no litter) and four amounts of litter $\left(0,80,160,240 \mathrm{~g} / \mathrm{m}^{2}\right)$. One hundred and five 20 - $\mathrm{cm}$ long $\times 18 \mathrm{~cm}$ diameter PVC collars (pots) (about $5.0 \times 10^{3} \mathrm{~cm}^{3}$ ) were used, and each treatment was replicated 15 times $(7$ treatments $\times 15$ replications $=105$ pots). Pots were filled with soil from the natural habitat that had been screened through a 40 -mesh screen to remove any seeds of the three study species present in the seed bank. Fifty seeds of each of the three species were sown in 105 pots (150 seeds per pot) on 28 July 2013. Any seeds of S. bungeana in the litter were removed before the litter was used. After seeds and litter were added to the pots, they were covered with $15 \mathrm{~cm} \times 15 \mathrm{~cm}$ 40 -meshscreensto prevent unintentional seed input and seed predation. The bottom of each pot was covered on the outside with nylon mesh to prevent loss of seeds through the drainage holes. The number of seedlings that emerged was recorded each week for 10 weeks, and seedlings were removed from the pots after they were counted. Seedlings of the two grasses were distinguished based on width of the leaf: leaves of Stipa were narrow like needles and those of Setaria were significantly wider than those of Stipa.

\section{Seed Persistence: Effect of Seed Position in Litter and Amount of Litter}

This experiment began on 28 July 2013 and ended 28 December 2014. The experimental design was the same as that described for seedling emergence. Seeds were retrieved from the pots on 28 December 2013, 28 June 2014 and 28 December 2014. For each species, seven treatments with five replicates each, i.e., 35 pots, were retrieved on each of the three dates, and the soil within each pot was sieved through a 40-mesh screen. Then, the number of seeds of each species remaining was counted and tested for viability via germination tests and the embryo cut test. Seeds with white and firm embryos were considered to be viable and those with soft and tan embryos non-viable. Dead non-germinated and dead germinated seeds could not be distinguished from each other.

\section{Statistical Analysis}

A three-way ANOVA was used to test the effect of seed position in litter, species and amount of litter on seedling emergence and effect of seed position in the litter, duration in the field (time since sowing) and amount of litter on seed persistence in soil. Percentages of viable seeds were $\log$ transformed before analysis, but only non-transformed data are shown in tables and figures. Duncan's multiple range tests were used to compare means among treatments. Data were analyzed using SPSS 21.0 software and the figures were created with Excel 2007.

\section{RESULTS}

\section{Seedling Emergence: Effect of Seed Position in Litter, Species and Amount of Litter}

Seed position in litter, species, amount of litter and their interactions had significant effects on cumulative seedling emergence. In general, seedling emergence of the three study species differed significantly (Table $1, P<0.001$ ). Seedling emergence of $S$. bungeana and $S$. glauca decreased with an increase in amount of litter for seeds sown on top of litter. However, seedling emergence of $L$. davurica did not differ significantly among different amounts of litter for seeds on top of the litter layer. For seeds sown beneath the litter layer, cumulative seedling emergence of each of the three species was significantly 
TABLE 1 | Effect of seed position (P), species (S), amount of litter (L) and their interactions on cumulative seedling emergence.

\begin{tabular}{lcccc}
\hline Source of variation & $\boldsymbol{d} \boldsymbol{f}$ & Mean square & $\boldsymbol{F}$ & $\boldsymbol{P}$ \\
\hline Position $(P)$ & 1 & 10692.900 & 374.413 & $<0.001$ \\
Species $(S)$ & 2 & 6671.233 & 233.594 & $<0.001$ \\
Amount of litter $(L)$ & 3 & 578.885 & 20.270 & $<0.001$ \\
$P \times S$ & 2 & 1922.533 & 67.318 & $<0.001$ \\
$P \times L$ & 3 & 1327.152 & 46.470 & $<0.001$ \\
$S \times L$ & 6 & 127.919 & 4.479 & $<0.001$ \\
$P \times S \times L$ & 6 & 261.930 & 9.171 & $<0.001$ \\
\hline
\end{tabular}

higher than that for seeds sown on top of the litter layer or directly on the bare soil (control = no litter) (Figure 1).

The highest cumulative seedling emergence of S. bungeana, S. glauca, and L. davurica was $36.13 \pm 3.64 \%, 76.00 \pm 2.25 \%$ and $31.47 \pm 3.04 \%$, respectively, for seeds sown beneath 160,240 , and $160 \mathrm{~g} / \mathrm{m}^{2}$ of litter, respectively. For L. davurica, seed position in the litter had a significant effect on cumulative seedling emergence, which was lower for seeds on top of the litter layer and on bare ground than for those positioned beneath the litter layer (Figure 1).

\section{Seed Persistence: Effect of Seed Position in Litter and Amount of Litter}

For all three species, percentage of viable seeds in the soil decreased significantly with an increase of time (duration) in the field (Figure 2). Seed position, seed duration in the field (time since sowing), amount of litter and some of their interactions (duration $\times$ amount of litter and position $\times$ duration $\times$ amount of litter) had significant effects on seed persistence of $S$. bungeana (Table 2) and S. glauca (Table 3). However, seed position and seed position $\times$ duration $\times$ amount of litter did not have a significant effect on seed persistence of L. davurica (Table 4).

Percentage of viable seeds in the field varied with seed position in litter, seed duration in the field and amount of litter. Percentage of viable seeds of $S$. bungeana was significantly higher for seeds on top of the litter layer than it was for those positioned beneath the litter layer or on bare ground, and it increased with an increase in amount of litter. After 5 months, $37.2 \%$ of S. bungeana seeds positioned on top of $240 \mathrm{~g} / \mathrm{m}^{2}$ litter were viable, whereas only $5.2 \%$ of those positioned beneath the same amount of litter were viable (Figure 2). Percentage of viable seeds of S. glauca in the field was significantly affected by seed position. After 5 months in the field, $46.4-53.2 \%$ of seeds positioned on top of the litter layer were viable, but only $15.2-28.4 \%$ of those positioned beneath different amounts of litter were viable. Decrease in number of viable seeds of S. glauca in the field was slower with an increase in time of burial compared to the other two species, and 2.4-12.4\% seeds were still viable after 1.5 year under different treatments (Figure 2). In contrast to S. glauca and S. bungeana, seed position of $L$. davurica did not have a significant effect on seed persistence. Percentage of viable seeds of $L$. davurica decreased quickly and was $\leq 3.6 \%$ for all the treatments after duration of 11 months in the field (Figure 2).

\section{DISCUSSION}

\section{Seedling Emergence: Effect of Seed Position in Litter, Species and Amount of Litter}

The effect of litter on seed germination and seedling establishment in grasslands ranged from strongly negative to slightly positive depending on environmental conditions, amount of litter and seed traits (Loydi et al., 2013). Our study showed that the effect of littler on seedling emergence ranged from slightly positive (S. bungeana) to positive (S. glauca and L. davurica) for seeds beneath the litter layer compared to those on bare soil. For seeds positioned on top of the litter layer, seedling emergence was slightly promoted, unchanged or inhibited depending on species and amount of litter compared to those on bare ground. Seed position in litter, species (seed traits) and amount of litter had significant effects on seedling emergence of the three common species on the Loess Plateau.

Low to medium amounts of litter $\left(<500 \mathrm{~g} / \mathrm{m}^{2}\right)$ had a positive effect on seedling recruitment in dry grasslands or under water-limited conditions (Loydi et al., 2013). This is consistent with our study, which clearly showed that litter had a positive effect on seedling emergence of all three study species when seeds were beneath the litter layer compared to those on bare soil. However, the beneficial effect for seeds beneath the litter layer varied with litter amount and species. For example, seedling emergence increased and then decreased as amount of litter increased in S. bungeana and L. davurica. However, a continual increase in seedling emergence with an increase in litter amount in S. glauca was observed. A possible interpretation of this result is that the presence of litter may maintain soil moisture or reduce the intensity of desiccation of seeds, which would facilitate germination and seedling establishment in a dry environment or during drought (Boeken and Orenstein, 2001; Eckstein and Donath, 2005; Rotundo and Aguiar, 2005; Donath and Eckstein, 2010; Loydi et al., 2013). Further, seedlings from seeds beneath the litter layer must reach light levels sufficient for photosynthesis, and a thick litter layer may reduce seedling emergence due to the lack of light (Facelli and Pickett, 1991b; Wellstein, 2012). Compared with small-seeded species, largeseeded species such as $S$. glauca can better cope with a thick litter layer (Krenova and Leps, 1996; Loydi et al., 2013), since they have sufficient resources for elongation of the hypocotyl to penetrate the litter layer and thus reach full sunlight (Hamrick and Lee, 1987).

However, when seeds were placed on top of the litter layer, seedling emergence was promoted, unchanged or inhibited depending on species and amount of litter. Seedlings from seeds on top of the litter layer must quickly make contact with the soil to order to avoid lethal desiccation (Hamrick and Lee, 1987). Seedling emergence of S. bungeana for seeds on top of $80 \mathrm{~g} / \mathrm{m}^{2}$ litter layer was slightly higher more than that of seeds sown on bare soil, indicating that resource investment for elongation of the radical allows $S$. bungeana to cope with this low amount of litter cover. For L. davurica, seedling emergence for seeds on top of the litter layer did not differ significantly 


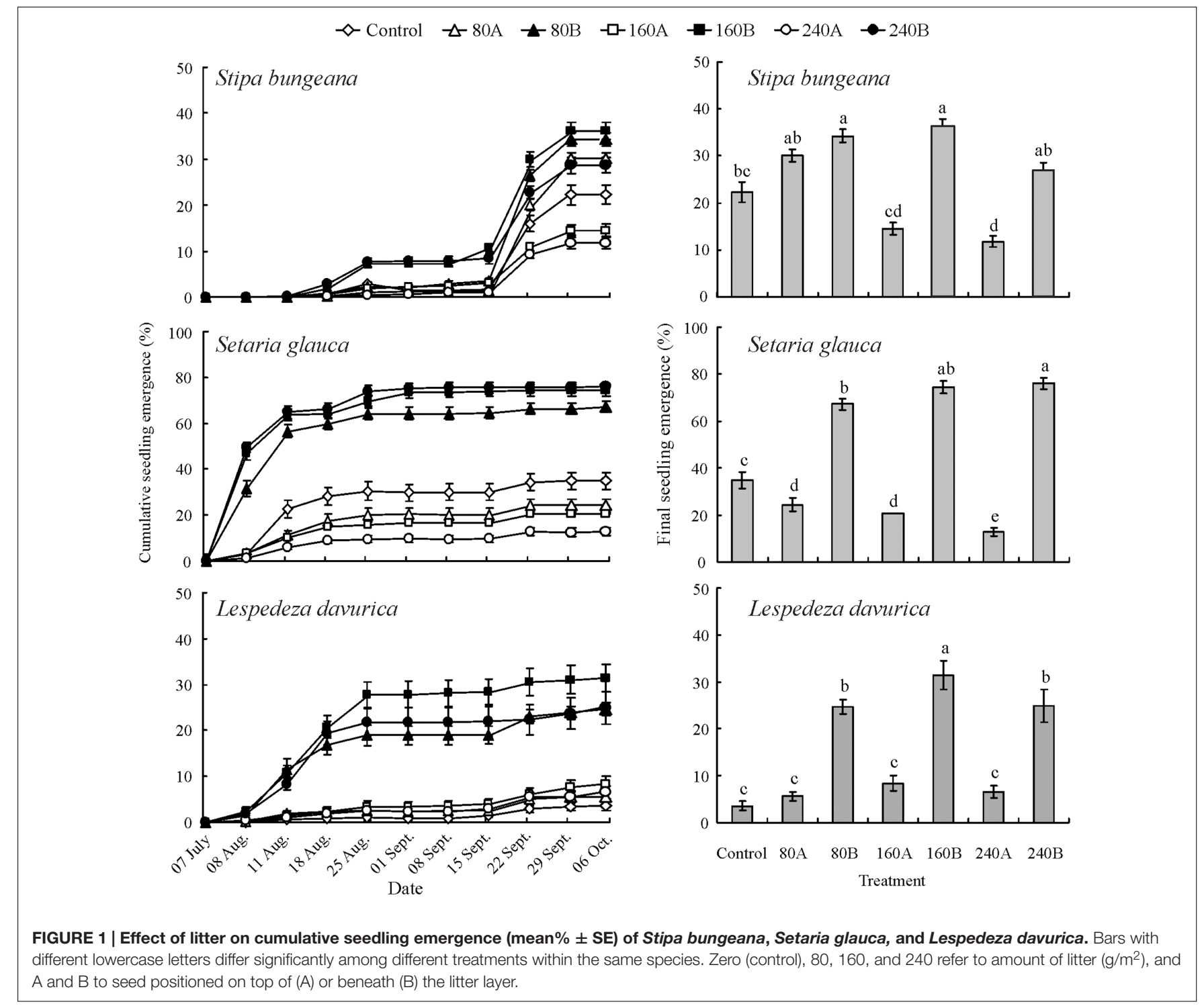

from those on bare soil. This showed that the positive effects of litter, such as attenuating temperature extremes and reducing water stress (Eckstein and Donath, 2005; Donath and Eckstein, 2010), was equal to the negative effect of litter, such as reducing soil-seed contact (Fowler, 1986; Chambers, 2000; Wellstein, 2012). However, the negative effects of litter outweighed its possible positive effects for S. glauca, and seedling emergence was significantly inhibited for seeds on top of the litter layer. Our findings highlight that the amount of litter in grassland ecosystems may serve as a potential indicator of plant diversity and composition over time due to its effects on timing of seed dispersal and seedling emergence.

\section{Seed Persistence: Effect of Seed Position in Litter and Amount of Litter}

Litter can modify soil temperature and soil moisture (Mackinney, 1929; Fowler, 1986; Boeken and Orenstein, 2001), and previous studies indicated that seed persistence can be affected by soil temperature, water potential and light transmission through their influence on germination, dormancy and aging (Long et al., 2009, 2015; Pakeman et al., 2012). Litter increased seed longevity of Bromus pictus through ameliorating temperature, which is one of the principal drivers of seed aging (Rotundo and Aguiar, 2005).

The presence of a litter layer may maintain soil moisture (Fowler, 1986; Boeken and Orenstein, 2001) and reduce temperature (Chambers and MacMahon, 1994), and temperature and moisture content are important factors that influence seed aging (Walters, 1998). Compared to seed position on top of the litter layer, its position beneath the litter layer had higher moisture content and lower temperature, and the moisture content of a seed at a given relative humidity increases as the temperature decreases (Roberts and Ellis, 1989; Facelli and Pickett, 1991b; Walters, 1998). Lower soil temperature and water availability promote persistence of desiccation-tolerant seeds (Long et al., 2009, 2015; Pakeman et al., 2012) by providing conditions that minimize seed aging, dormancy loss (Davis et al., 


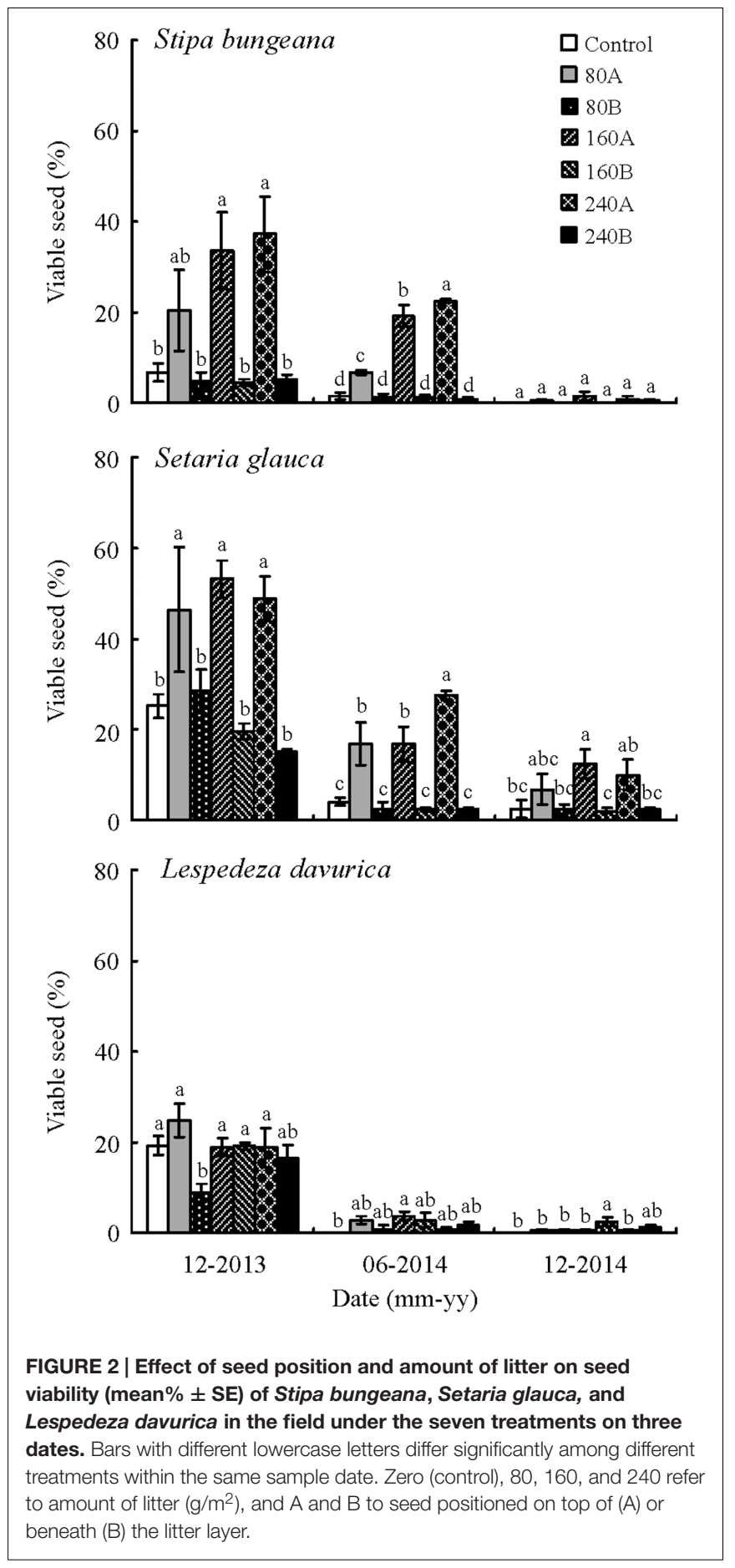

2005) and microbial activity (Schafer and Kotanen, 2003). Thus, the effect of litter on seed persistence depends on whether temperature or soil moisture has a greater effect on seed longevity. Our study showed that on the Loess Plateau seeds of S. bungeana and S. glauca on top of the litter layer persist longer than those on the bare soil or beneath the litter layer, which indicates that soil moisture plays a more important role in seed persistence than temperature.
TABLE 2 | Three-way ANOVA of the effects of seed position (P), duration (D), amount of litter (L), and their interaction on seed viability of Stipa bungeana in the field.

\begin{tabular}{lcccc}
\hline Source of variation & $\boldsymbol{d} \boldsymbol{f}$ & Mean square & $\boldsymbol{F}$ & $\boldsymbol{P}$ \\
\hline Position $(P)$ & 1 & 6.220 & 83.075 & $<0.001$ \\
Duration $(D)$ & 2 & 7.316 & 97.712 & $<0.001$ \\
Litter amount $(L)$ & 3 & 0.664 & 8.870 & $<0.001$ \\
$P \times D$ & 2 & 1.105 & 14.756 & $<0.001$ \\
$P \times L$ & 3 & 0.847 & 11.306 & $<0.001$ \\
$D \times L$ & 6 & 0.091 & 1.218 & 0.304 \\
$P \times D \times L$ & 6 & 0.158 & 2.114 & 0.058
\end{tabular}

TABLE 3 | Three-way ANOVA of the effects of seed position (P), duration (D), amount of litter (L), and their interaction on seed viability of Setaria glauca in the field.

\begin{tabular}{lcccc}
\hline Source of variation & $\boldsymbol{d} \boldsymbol{f}$ & Mean square & $\boldsymbol{F}$ & $\boldsymbol{P}$ \\
\hline Position $(P)$ & 1 & 4.279 & 42.054 & $<0.001$ \\
Duration $(D)$ & 2 & 8.950 & 87.963 & $<0.001$ \\
Litter amount $(L)$ & 3 & 0.581 & 5.708 & 0.001 \\
$P \times D$ & 2 & 0.647 & 6.363 & 0.003 \\
$P \times L$ & 3 & 0.520 & 5.113 & 0.003 \\
$D \times L$ & 6 & 0.157 & 1.542 & 0.173 \\
$P \times D \times L$ & 6 & 0.100 & 0.985 & 0.440 \\
\hline
\end{tabular}

TABLE 4 | Three-way ANOVA of the effects of seed position (P), duration (D), amount of litter (L), and their interaction on seed viability of Lespedeza davurica in the field.

\begin{tabular}{lcrrr}
\hline Source of variation & $\boldsymbol{d f}$ & Mean square & $\boldsymbol{F}$ & \multicolumn{1}{c}{$\boldsymbol{P}$} \\
\hline Position $(P)$ & 1 & 0.010 & 0.237 & 0.627 \\
Duration $(D)$ & 2 & 14.817 & 349.016 & $<0.001$ \\
Litter amount $(L)$ & 3 & 0.255 & 6.010 & 0.001 \\
$P \times D$ & 2 & 0.214 & 5.029 & 0.008 \\
$P \times L$ & 3 & 0.207 & 4.867 & 0.003 \\
$D \times L$ & 6 & 0.117 & 2.754 & 0.016 \\
$P \times D \times L$ & 6 & 0.044 & 1.027 & 0.413 \\
\hline
\end{tabular}

Percentage of viable seeds of $S$. bungeana was 20.4, 33.6, and $37.2 \%$ for seeds positioned on top of 80,160 , and $240 \mathrm{~g} / \mathrm{m}^{2}$ litter layer, respectively, after 5 months, whereas only $6.8 \%$ of those on bare soil were viable. After 11 months, percentage of viable seeds was $6.8,19.2$, and $22.4 \%$ for seeds positioned on top of 80,160 , and $240 \mathrm{~g} / \mathrm{m}^{2}$ litter layer, respectively, all of which were significantly higher than those beneath different amounts of litter layer and on bare soil (1.6\%). Hu et al. (2014) reported that all S. bungeana seeds had lost viability after 5 months of burial at $5 \mathrm{~cm}$, whereas 12 and $4 \%$ of those on the soil surface were viable after 5 and 12 months, respectively. Our results indicated that litter had a positive effect on seed persistence, and percentage of viable seeds increased with amount of litter for seeds on top of litter layer. One possible interpretation of this result is that seeds of $S$. bungeana have a long awn that causes them to be easily trapped in the litter, thus preventing seed contact with the surrounding soil. As such, the seeds failed to germinate or germination was delayed (Ruprecht and Szabo, 2012). 
Seeds of S. glauca have been reported to live for 15 (Dawson and Bruns, 1975), 30 (Kivilaan and Bandurski, 1981) and 38 (Toole and Brown, 1946) years in soil. Thus, they can form a long-lived persistent seed bank. However, in our study seeds of S. glauca lost viability after 11 months. Seedling emergence of S. glauca from August to October was $>67 \%$ for seed beneath the litter layer with different amounts of litter, and it was $12.7 \%$ even for those on top of $240 \mathrm{~g} / \mathrm{m}^{2}$ litter layer. As time increases, most S. glauca seeds could germinate if exposed to light and adequate soil moisture. Seeds of this species buried under natural temperatures in Kentucky (USA) in November and exhumed in June and July germinated to $70-100 \%$ in light and darkness at $15 / 6,20 / 10,25 / 15,30 / 15$, and $35 / 20^{\circ} \mathrm{C}$ (Baskin et al., 1996).

Seed persistence of S. glauca and S. bungeana was affected by amount of litter and seed position in the litter layer. However, seed persistence of $L$. davurica was affected by amount of litter but not by position in the litter. The large seeds of S. glauca and the awned seeds of $S$. bungeana are suspended within the litter or lodged on top of it and thus do not make contact with soil. However, the small seeds of $L$. davurica on top of the litter layer may 'percolate' through the litter layer and then germinate when conditions are favorable for them to do so (Rotundo and Aguiar, 2005; Ruprecht and Szabo, 2012). The fact that the soil seed bank drives multiple ecosystem functions related to community dynamics and composition suggests that seed persistence should be taken into account in assessing the impact of changes in land use and climate.

\section{PRACTICAL IMPLICATIONS}

The present study clearly demonstrates that litter plays a key role in regulating seed germination, seedling emergence and seed persistence. Specifically, a moderate litter amount

\section{REFERENCES}

Baskin, C. C., and Baskin, J. M. (2014). Seeds: Ecology, Biogeography, and Evolution of Dormancy and Germination. Second edition. San Diego, CA: Elsevier/Academic Press.

Baskin, C. C., Baskin, J. M., and El-Moursey, S. A. (1996). Seasonal changes in germination responses of buried seeds of the weedy summer annual grass Setaria glauca. Weed Res. 36, 319-324. doi: 10.1111/j.1365-3180.1996.tb01662.x

Boeken, B., and Orenstein, D. (2001). The effect of plant litter on ecosystem properties in a Mediterranean semi-arid shrubland. J. Veg. Sci. 12, 825-832. doi: $10.2307 / 3236870$

Bossuyt, B., and Honnay, O. (2008). Can the seed bank be used for ecological restoration? An overview of seed bank characteristics in European communities. J. Veg. Sci. 19, 875-884. doi: 10.3170/2008-8-18462

Chambers, J. C. (2000). Seed movements and seedling fates in disturbed sagebrush steppe ecosystems: implications for restoration. Ecol. Appl. 10, 1400-1413. doi: $10.2307 / 2641294$

Chambers, J. C., and MacMahon, J. A. (1994). A day in the life of a seed: movements and fates of seeds and their implications for natural and managed systems. Annu. Rev. Ecol. Syst. 25, 263-292. doi: 10.1146/annurev.es.25.110194. 001403

Cheng, J. M., Jing, Z. B., Jin, J. W., and Gao, Y. (2014). Restoration and utilization mechanism of degraded grassland in the semi-arid region of Loess Plateau. Scient. Sin. Vitae 44, 267-279. doi: 10.1360/052013-280 favors seedling emergence, whereas continual increasing litter decrease seedling emergence. These results imply that moderate utilization will be beneficial for vegetation restoration of longterm enclosure grassland, in which the amount of litter is high. Also, we propose that the amount of litter could be a good indicator for effective restoration and for grassland management. Our study showed that maintaining the amount of litter between $80-160 \mathrm{~g} / \mathrm{m}^{2}$ is optimal for S. bungeanadominated grassland on the Loess Plateau. Moreover, we also found that seeds beneath litter significantly improved seedling emergence regardless of litter amount, suggesting that moderate disturbance favoring downward movement of seeds may accelerate vegetation restoration. Our study supports the notion that litter accumulation resulting from long term enclosure decreases the capability of grassland regeneration and suggests that moderate utilization is necessary for maintaining a healthy grassland ecosystem on the Loess Plateau, with litter as a potential indicator.

\section{AUTHOR CONTRIBUTIONS}

$\mathrm{RZ}, \mathrm{XH}$, and $\mathrm{YW}$ conceived the topic. RZ performed the experiments. $\mathrm{RZ}$ and $\mathrm{XH}$ analyzed all statistical data. $\mathrm{RZ}$ and $\mathrm{XH}$ wrote the manuscript. JB and CB revised several version of the manuscript.

\section{ACKNOWLEDGMENT}

This work was supported by the Programme of Introducing Talents of Discipline to Universities (B12002), Fundamental Research Funds for the Central Universities (lzujbky-2016-11) and the National Natural Science Fund (31672473).

Cheng, J. M., Wan, H. E., Hu, X. M., and Zhao, Y. Y. (2006). Accumulation and decomposition of litter in the semiarid enclosed grassland. Acta Ecol. Sin. 26, 1207-1212.

Culpepper, A. S., and Sheldon, Y. S. (1999). Basis for antagonism in mixtures of bromoxynil plus quizalofop-P applied to yellow foxtail (Setaria glauca). Weed Technol. 13, 515-519.

Davis, A. S., Cardina, J., Forcella, F., Johnson, G. A., Kegode, G., Lindquist, J. L., et al. (2005). Environmental factors affecting seed persistence of annual weeds across the US cornbelt. Weed Sci. 53, 860-868. doi: 10.1614/WS-05-064R1.1

Dawson, J. H., and Bruns, V. F. (1975). Longevity of barnyardgrass, green foxtail, and yellow foxtail seeds in soil. Weed Sci. 23, 437-440.

Donath, T. W., and Eckstein, R. L. (2008). Grass and oak litter exert different effects on seedling emergence of herbaceous perennials from grasslands and woodlands. J. Ecol. 96, 272-280. doi: 10.1111/j.1365-2745.2007.01338.x

Donath, T. W., and Eckstein, R. L. (2010). Effects of bryophytes and grass litter on seedling emergence vary by vertical seed position and seed size. Plant Ecol. 207, 257-268. doi: 10.1007/s11258-009-9670-8

Dumont, B., Farruggia, A., Garel, J. P., Bachelard, P., Boitier, E., and Frain, M. (2009). How does grazing intensity influence the diversity of plants and insects in a species-rich upland grassland on basalt soils? Grass Forage Sci. 64, 92-105. doi: 10.1111/j.1365-2494.2008.00674.x

Eckstein, R. L., and Donath, T. W. (2005). Interactions between litter and water availability affect seedling emergence in four familial pairs of floodplain species. J. Ecol. 93, 807-816. doi: 10.1111/j.1365-2745.2005.01015.x 
Eckstein, R. L., Pereira, E., Milbau, A., and Graae, B. J. (2011). Predicted changes in vegetation structure affect the susceptibility to invasion of bryophytedominated subarctic heath. Ann. Bot. 108, 177-183. doi: 10.1093/aob/ mcr097

Egawa, C., Koyama, A., and Tsuyuzaki, S. (2009). Relationships between the developments of seedbank, standing vegetation and litter in a post-mined peatland. Plant Ecol. 203, 217-228. doi: 10.1007/s11258-9536-5

Egawa, C., and Tsuyuzaki, S. (2013). The effects of litter accumulation through succession on seed bank formation for small- and large-seeded species. J. Veg. Sci. 24, 1062-1073. doi: 10.1111/jvs.12037

Facelli, J. M., and Pickett, S. T. A. (1991a). Plant litter: light interception and effects on an old-field plant community. Ecology 72, 1024-1031. doi: 10.2307/19 40602

Facelli, J. M., and Pickett, S. T. A. (1991b). Plant litter: its dynamics and effects on plant community structure. Bot. Rev. 57, 1-32. doi: 10.1007/BF028 58763

Fowler, N. L. (1986). Microsite requirements for germination and establishment of three grass species. Am. Midl. Nat. 115, 131-145. doi: 10.2307/242 5843

Gibson, D. J., and Good, R. E. (1987). The seedling habitat of pinus echinata and Melampyrum lineare in oak-pine forest of the New Jersey Pinelands. Oikos 49, 91-100. doi: $10.2307 / 3565558$

Grime, J. P. (2001). Plant Strategies, Vegetation Processes, and Ecosystem Properties. Second edition. Chichester: Wiley.

Hamrick, J. L., and Lee, J. M. (1987). Effect of soil surface topography and litter cover on the germination, survival, and growth of musk thistle (Carduus nutans). Am. J. Bot. 74, 451-457. doi: 10.2307/2443821

Hodgson, J. G., and Grime, J. P. (1990). "The role of dispersal mechanisms, regenerative strategies and seed banks in the vegetation dynamics of the British landscape," in Species Dispersal Inagricultural Habitats, eds R. G. H. Bunce and D. C. Howard (London: Belhaven Press), 65-81.

Holmgren, M., Scheffer, M., and Huston, M. A. (1997). The interplay of facilitation and competition in plant communities. Ecology 78, 1966-1975. doi: 10.2307/ 2265937

Hovstad, K. A., and Ohlson, M. (2008). Physical and chemical effects of litter on plant establishment in semi-natural grasslands. Plant Ecol. 196, 251-260. doi: 10.1007/s11258-00709349-y

Hu, X. W., Wu, Y. P., Ding, X. Y., Zhang, R., Wang, Y. R., Baskin, J. M., et al. (2014). Seed dormancy, seedling establishment and dynamics of the soil seed bank of Stipa bungeana (Poaceae) on the Loess Plateau of northwestern China. PLOS ONE 9:e112579. doi: 10.1371/journal.pone. 0112579

Jones, F. E., and Esler, K. J. (2004). Relationship between soil-stored seed banks and degradation in eastern Nama Karoo rangelands (South Africa). Biodiver. Conserv. 13, 2027-2053. doi: 10.1023/B:BIOC.0000040007. 33950.38

Kettenring, K. M., Gardner, G., and Galatowitsch, S. M. (2006). Effect of light on seed germination of eight wetland Carex species. Ann. Bot. 98, 869-874. doi: $10.1093 / \mathrm{aob} / \mathrm{mcl} 170$

Kivilaan, A., and Bandurski, R. S. (1981). The one hundred-year period for Dr. Beal's seed viability experiment. Am. J. Bot. 68, 1290-1292. doi: 10.2307/ 2443054

Krenova, Z., and Leps, J. (1996). Regeneration of a Gentiana pneumonanthe population in an oligotrophic wet meadow. J. Veg. Sci. 7, 107-112. doi: 10.2307/ 3236422

Lin, H., Tong, X., Zhao, Z. P., Sun, C. Y., Liu, J. Y., Shao, Q. Q., et al. (2013). Effects of grassland restoration programs on ecosystems in arid and semiarid China. J. Environ. Manage. 117, 268-275. doi: 10.1016/j.jenvman.2012.12.040

Liu, G., Wan, L., He, F., Tong, Z., Liu, Z., and Li, X. (2016). Effects of litter, seed position, and water availability on establishment of seedlings for two semiarid grass species. Plant Ecol. 217, 277-287. doi: 10.1007/s11258-016-0569-x

Liu, J., Li, S., Ouyang, Z., Tam, C., and Chen, X. (2008). Ecological and socioeconomic effects of China's policies for ecosystem services. Proc. Natl. Acad. Sci. U.S.A. 105, 9477-9482. doi: 10.1073/pnas. 0706436105

Long, R. L., Gorecki, M. J., Renton, M., Scott, J. K., Colville, L., Goggin, D. E., et al. (2015). The ecophysiology of seed persistence: a mechanistic view of the journey to germination or demise. Biol. Rev. 90, 31-59. doi: 10.1111/brv.12095
Long, R. L., Steadman, K. J., Panetta, F. D., and Adkins, S. W. (2009). Soil type does not affect seed ageing when soil water potential and temperature are controlled. Plant Soil 320, 131-140. doi: 10.1007/s11104-0089878-8

Loydi, A., Eckstein, R. L., Otte, A., and Donath, T. W. (2013). Effects of litter on seedling establishment in natural and semi-natural grasslands: a meta-analysis. J. Ecol. 101, 454-464. doi: 10.1111/1365-2745.12033

Mackinney, A. L. (1929). Effects of forest litter on soil temperature and soil freezing in autumn and winter. Ecology 10, 312-321. doi: 10.2307/1929507

Michaela, D., and Wolfgang, S. (2009). The relationship between soil seed bank, above-ground vegetation and disturbance intensity on old field successional permanent plots. Appl. Veg. Sci. 12, 415-428. doi: 10.1111/j.1654-109X.2009. 01036.x

Pakeman, R. J., Small, J. L., and Torvell, L. (2012). Edaphic factors influence the longevity of seeds in the soil. Plant Ecol. 213, 57-65. doi: 10.1007/s11258-0110006-0

Pettit, N. E., Froend, R. H., and Ladd, P. G. (1995). Grazing in remnant woodland vegetation: changes in species composition and life form groups. J. Veg. Sci. 6, 121-130. doi: $10.2307 / 3236263$

Quested, H., and Eriksson, O. (2006). Litter species composition influences the performance of seedlings of grassland herbs. Funct. Ecol. 20, 522-532. doi: 10.1111/j.1365-2435.2006.01131.x

Quested, H. M., Callaghan, T. V., Cornelissen, J., and Press, M. C. (2005). The impact of hemiparasitic plant litter on decomposition: direct, seasonal and litter mixing effects. J. Ecol. 93, 87-98. doi: 10.1111/j.0022-0477.2004. 00951.x

Roberts, E. H., and Ellis, R. H. (1989). Water and seed survival. Ann. Bot. 63, 39-52. doi: 10.1093/oxfordjournals.aob.a087727

Rotundo, J. L., and Aguiar, M. R. (2005). Litter effects on plant regeneration in arid lands: a complex balance between seed retention, seed longevity and soil-seed contact. J. Ecol. 93, 829-838. doi: 10.1111/j.1365-2745.2005. 01022.x

Ruprecht, E., Enyedi, M. Z., Eckstein, R. L., and Donath, T. W. (2010a). Restorative removal of plant litter and vegetation 40 years after abandonment enhances re-emergence of steppe grassland vegetation. Biol. Conserv. 143, 449-456. doi: 10.1016/j.biocon.2009.11.012

Ruprecht, E., Józsa, J., Ölvedi, T. B., and Simon, J. (2010b). Differential effects of several "litter" types on the germination of dry grassland species. J. Veg. Sci. 21, 1069-1081. doi: 10.1111/j.1654-1103.2010.01206.x

Ruprecht, E., and Szabo, A. (2012). Grass litter is a natural seed trap in long-term undisturbed grassland. J. Veg. Sci. 23, 495-504. doi: 10.1111/j.1654-1103.2011. 01376.x

Schafer, M., and Kotanen, P. M. (2003). The influence of soil moisture on losses of buried seeds to fungi. Acta Oecol. 24, 255-263. doi: 10.1016/j.actao.2003. 09.001

Steel, M. S., Cavers, P. B., and Lee, S. M. (1983). The biology of Canadian weeds. 59. Setaria glauca (L.) Beauv.and S. verticillata (L.) Beauv. Can. J. Plant Sci. 63, 711-725. doi: 10.4141/cjps83-088

Toole, E. H., and Brown, E. (1946). Final results of the Duvelburied seed experiment. J. Agric. Res. 72, 201-210.

Unkovich, M., and Nan, Z. (2008). Problems and prospects of grassland agroecosystems in western China. Agric. Ecosyst. Environ. 124, 1-2. doi: 10 1016/j.agee.2007.08.012

Van der Valk, A. G., and Verhoeven, J. T. A. (1988). Potential role of seed banks and understorey vegetation in restoring quaking fens from floating forests. Plant Ecol. 76, 3-13. doi: 10.1007/BF00047383

Vellend, M., Lechowicz, M. J., and Waterway, M. J. (2000). Germination and establishment of forest sedges (Carex, Cyperaceae): tests for home-site advantage and effects of leaf litter. Am. J. Bot. 87, 1517-1525. doi: 10.2307/ 2656878

Walters, C. (1998). Understanding the mechanisms and kinetics of seed aging. Seed Sci. Res. 8, 223-244. doi: 10.1016/j.plaphy.2012.07.031

Wellstein, C. (2012). Seed-litter-position drives seedling establishment in grassland species under recurrent drought. Plant Biol. 14, 1006-1010. doi: 10.1111/j.14388677.2012.00635.x

Xiong, S., and Nilsson, C. (1999). The effects of plant litter on vegetation: a meta-analysis. J. Ecol. 87, 984-994. doi: 10.1046/j.1365-2745.1999.00414.x 
Xu, B., Gao, Z., Wang, J., and Huang, W. X. J. (2013). Morphological changes in roots of Bothriochloa ischaemum intercropped with Lespedeza davurica following phosphorus application and water stress. Plant Biosyst. 149, 1-9. doi: $10.1080 / 11263504.2013 .823132$

Zhao, G., Mu, X., Wen, Z., Wang, F., and Gao, P. (2013). Soil erosion, conservation, and eco-environment changes in the Loess Plateau of China. Land Degrad. Dev. 24, 333-343. doi: 10.1002/ldr.2246

Conflict of Interest Statement: The authors declare that the research was conducted in the absence of any commercial or financial relationships that could be construed as a potential conflict of interest.
The reviewer NK and handling Editor declared their shared affiliation, and the handling Editor states that the process nevertheless met the standards of a fair and objective review.

Copyright (๑) 2017 Zhang, Hu, Baskin, Baskin and Wang. This is an open-access article distributed under the terms of the Creative Commons Attribution License (CC BY). The use, distribution or reproduction in other forums is permitted, provided the original author(s) or licensor are credited and that the original publication in this journal is cited, in accordance with accepted academic practice. No use, distribution or reproduction is permitted which does not comply with these terms. 